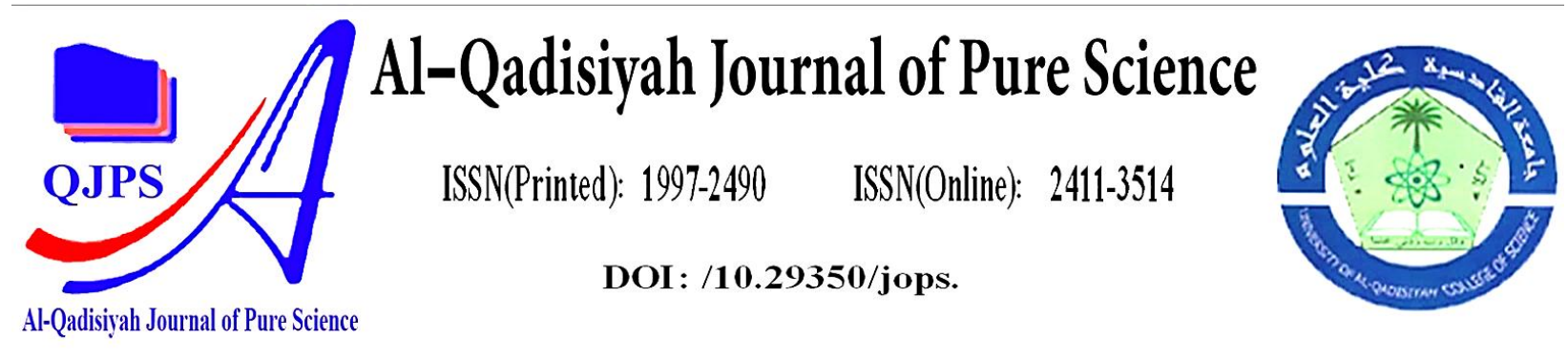

http://qu.edu.iq/iournalsc/index.php/IOPS

\title{
The Prevalence of Uropathogenic Escherichia coli Strains among Outpatients with Urinary Tract Infection in Zakho City, Iraq
}

\begin{abstract}
bAuthors Names
ABSTRACT

a.Marwa Subhi Ibrahim

b.Haval Mohammed

Khalid

c.Wijdan M S Mer

\section{Article History}

Received on:24/6/2021

Revised on: 28/8/2021

Accepted on: 30/8/2021

Keywords:

risk factors, uidA gene

UPEC

DOI: : https://doi.org/10.29350 jops.2021.26. 5.1366

Uropathogenic Escherichia coli (UPEC) is the most common strain of Escherichia coli that causes urinary tract infection (UTI) in human. This study involved the prevalence of UPEC among outpatients with UTIs attending three major hospitals in Zakho city. Four hundred urine samples were collected from patients with UTIs of both sexes and different ages ( $\leq 1$ year to over 50 years), during the period from July 2018 until January 2019. All urine samples were analyzed by conventional bacteriological method for the presence of $E$. coli, while molecular method was used for the presence of species-specific uidA gene of the isolated E. coli. From the enrolled patients, 35.25\% (141/400) of them were infected with UPEC. The rate was higher in females than males $(90.78 \%$ vs 9.22\%), respectively. Among both sexes, the age group 41-50 years showed the highest rate $(46.67 \%)$ of infection, furthermore, among all ages, married patients showed slightly higher prevalence than un-married one (38\% vs $32.5 \%)$, respectively. The rate of UTI was higher among urban inhabitants $(40.56 \%)$ than others. During the months of the year, the peak $(90.48 \%)$ of infection in both sexes was during December while the lowest rates (13.64\%) was during January. The study highlights that, the UPEC is one of the most common bacteria that causes UTI in humans and various risk factors contribute in its spreading in the community.
\end{abstract}

MSC:

a Department of Nursing, Zakho Technical Institute, Duhok Polytechnic University, Duhok, Iraq, Marwa.subhi@dpu.edu.Krd b Department of Biology, Faculty of Science, University of Zakho, Zakho, Iraq, haval.khalid@uoz.edu.krd, wijdan.mero@uoz.edu.krd 


\section{Introduction}

Urinary tract infection (UTI) is one of the most common bacterial infections in humans and medically is the second most bacterial infection after respiratory tract infection,[38,25] this infection is acquired in all ages from newborn to geriatric. [39] The Gram negative bacteria, especially Escherichia coli (E. coli) is considered as one of the most causative agents causing UTIs. [8] Escherichia coli is a member of family Enterobacteriaceae. [34] It has been believed that within a short time after birth it became the main constituent of the normal intestinal flora of both humans and animals, which in turn take a mutual benefit from each other. ${ }^{[35]}$ Besides $E$. coli is a harmless pathogen, there is an alternative face to be a highly adapted pathogen, which mostly through gene gaining cause several infections ranging from intestinal to extra-intestinal diseases including meningitis, septicemia and infection of the urinary tract. [11]

Various risk factors increase the chances for developing UTIs, such as sex, age, immune deficiency, primary diseases such as renal failure and the effect of urological catheter despite to the facts of the microbial etiology. [41] The recorded rates of complicated UTIs were increased worldwide, especially in developing countries. [10] Approximately $10 \%$ of humans have UTI sometime during their lifetime. [15] It is estimated that around 150 million cases of UTIs occur annually worldwide, ${ }^{[24,40]}$ resulting in over 6 billion dollars in direct health care expenditures.[24] The UPEC is responsible for about $80-90 \%$ of all UTI in all patients regardless of age with higher prevalence in females than males, ${ }^{[25]}$ yearly about $11 \%$ of women were infected by UTI, ${ }^{[14]}$ and more than $50 \%$ of them were infected at least one time, as many as $20-40 \%$ of them are reinfected within one year. [38] The higher prevalence of UTIs among females is mostly due to the anatomical and physiological characters that facilitate the infection. Therefore, UTIs is mostly a female disease. [15] Untreated asymptomatic bacteriuria (ASB) is responsible for the development of symptomatic bacteriuria approximately $30 \%$ of cystitis and up to $50 \%$ of pyelonephritis. [25] In developing countries, the prevalence of ASB is three times higher than in developed countries. [3]

Several studies have been performed in Kurdistan Region-Iraq. Such as in Zakho city, a rate of $43.20 \%$ isolates of $E$. coli was detected among UTIs patients. [22] While in Duhok city, a much higher rate of UPEC infection which was 74.4\% (276/371) was reported in women. [20] Furthermore, in Erbil and Sulaimania cities, high prevalence (42\% vs 30\%, respectively) of the UPEC were isolated from pure and mixed cultures were. [4] Another study in Erbil city, also, 
reported a high prevalence of UPEC accounting for 58.57\% in UTIs outpatients. [23] Therefore, due to limited studies in this aspect the present study was adapted to investigate the prevalence of UPEC among the UTI cases referred to the laboratories in three major hospitals of Zakho city, Duhok governorate, Kurdistan-Iraq, using biochemical tests and molecular identification by species-specific gene of isolated UPEC. Furthermore, to correlate between the UPEC and some risk factors and seasonal variations.

\section{Materials and Methods}

\subsection{Sample Collection}

In this study 400 clinical midstream urine samples were collected from the enrolled outpatients of both sexes and different ages ( $\leq 1$ to above 50 years) referred by the urologestis to the laboratories of the three major hospitals in Zakho city, during the period from July 2018 until January 2019. During the sample collection period, patients were informed about the right way how to collect the urine sample and each patient was provided with a sterile labelled disposable screw-capped container. The collected samples were cultured on different culture media in the Microbiology Laboratory of Zakho General hospital and both Maternity and Emergency hospitals, then plates with pure colonies of uropathogenic E. coli were subcultured and the positive plates were subjected in the microbiology laboratory of the Medical Technology Department-Zakho Technical Institute for performing biochemical tests. The molecular study of the isolats was performed in the Molecular research laboratory of Biology Department-Faculty of Science-University of Zakho.

\subsection{Laboratory Diagnosis}

Identification of the isolated E.coli was performed by the morphological characterization of the isolated UPEC colonies on the culture media according to their colony morphology on selected media (MacConkey and blood agar). [13] The isolated colonies were tested by gram stain according to the protocol supplied with the kit (Atom scientific-UK). Furthermore, some biochemical tests were performed, for further confirmation of the isolated bacteria, such as indole tests, methyl red test, citrate utilization test and triple sugar iron agar (TSI). [27] For E. coli preservation, $0.5 \mathrm{ml}$ of overnight incubated nutrient broth containing $E$. coli was added to sterile tubes containing $0.5 \mathrm{ml}$ sterile glycerol, mixed well, and stored at $-20^{\circ} \mathrm{C}$, for 6 months. [9] 


\subsection{Molecular Diagnosis}

The genomic DNA of the E. coli was extracted according to the protocol supplied with the Kit (PrimePrep ${ }^{\mathrm{TM}}$ Genomic DNA Extraction Kit/GeNet Bio-Korea). The concentration and purity of the genomic DNA of each sample was determined using a Nanodrop spectrophotometer 2000 (Thermo scientific, USA), then used for PCR amplification. The uidA primer was used as a species-specific primer for $E$. coli identification and for amplifying the target uidA gene as shown in Table (1). The PCR amplification reaction of each sample is shown in Table (2). The prepared reaction tubes were inserted in the thermal cycler for amplification, the amplification condition is shown in Table (3). After amplification, the PCR product was confirmed by running in gel electrophoresis for one hr using 1.2\% (w/v) of agarose prepared in 1x TBE buffer.

Table 1: Primers used for detection of species-specific gene in UPEC

\begin{tabular}{lccc}
\hline Primer & $\begin{array}{c}\text { DNA sequence 5'- 3' } \\
\text { (forward and reverse) }\end{array}$ & $\begin{array}{c}\text { Amplified } \\
\text { product (bp) }\end{array}$ & Reference or source \\
\hline \multirow{2}{*}{ uidA } & $\begin{array}{l}\text { F-CATTACGGCAAAGTGTGGGTCAAT } \\
\text { R-CCATCAGCACGTTATCGAATCCTT }\end{array}$ & $658 \mathrm{bp}$ & \\
\hline
\end{tabular}

Table 2: Components of the PCR reaction

\begin{tabular}{lc}
\hline \multicolumn{1}{c}{ Components } & Volume $(\mu \mathrm{l})$ \\
\hline Master mix & $5 \mu \mathrm{l}$ \\
\hline Forward primer $(10 \mathrm{pmol} / \mu \mathrm{l})$ & $2 \mu \mathrm{l}$ \\
\hline Reverse primer $(10 \mathrm{pmol} / \mu \mathrm{l})$ & $2 \mu \mathrm{l}$ \\
\hline Genomic DNA $(25-50 \mathrm{ng} / \mu \mathrm{l})$ & $2 \mu \mathrm{l}$ \\
\hline PCR grade water & $9 \mu \mathrm{l}$ \\
\hline Grand Total & $20 \mu \mathrm{l}$
\end{tabular}

Table 3: The amplification condition of species-specific PCR analysis for uidA primer

\begin{tabular}{|c|c|c|c|c|c|}
\hline $\begin{array}{c}\text { Initial } \\
\text { denaturation }\end{array}$ & Denaturation & Annealing & Extension & $\begin{array}{c}\text { Final } \\
\text { extension }\end{array}$ & Reference \\
\hline $94^{\circ} \mathrm{C}$ & $92^{\circ} \mathrm{C}$ & $58^{\circ} \mathrm{C}$ & $72^{\circ} \mathrm{C}$ & $72^{\circ} \mathrm{C}$ & \multirow{3}{*}{ [1] } \\
\hline $10 \mathrm{~min}$ & $1 \mathrm{~min}$ & $1 \mathrm{~min}$ & $30 \mathrm{sec}$. & $5 \mathrm{~min}$ & \\
\hline 1 cycle & & 35 cycles & & 1 cycle & \\
\hline
\end{tabular}




\subsection{Statistical Analysis}

Graph Pad Prism 8.1 software was performed for statistical analysis. The chi-square test was used to find out the significant differences between categories and P-value $\leq 0.05$ considered significant. Krona Excel template was used to compare the communication of two or more groups (https://sourceforge. net/p/krona/home/krona/?version =8).

\section{Results}

During the present study, 35.25\% (141/400) of enrolled outpatients were infected with UPEC, with a higher rate in females than males (90.78\% vs 9.22\%), respectively, as shown in Table (4).

\section{Table 4: Distribution of UPEC among outpatients with UTI}

\begin{tabular}{ccccccc}
\hline \multirow{2}{*}{$\begin{array}{c}\text { No. of examined } \\
\text { urine samples }\end{array}$} & \multicolumn{2}{c}{ Total No. of } & \multicolumn{4}{c}{ Sexes } \\
\cline { 2 - 6 } & \multicolumn{2}{c}{ Infections } & & Females & \multirow{2}{*}{ Males } \\
\cline { 2 - 7 } & No. & $\mathbf{\%}$ & No. & \% & No. & $\%$ \\
\hline 400 & 141 & 35.25 & 128 & 90.78 & 13 & 9.22 \\
\hline
\end{tabular}

All UPEC isolates were identified by the cultural characters on MacConkey and blood agars,[13] in addition to biochemical tests, that confirmed the isolated bacteria are E. coli strains which included; positive result for both indole and methyl red tests, negative reaction with Gram's stain rod-shaped, that is unable to utilize citrate and the production of acids in both slant and butt, with gas production and without $\mathrm{H}_{2} \mathrm{~S}$ production in TSI agar. [34] The amplified isolated E. coli produced a single band of a target uidA gene with a molecular weight of 670 bps that confirmed its presence as shown in Figure (1).

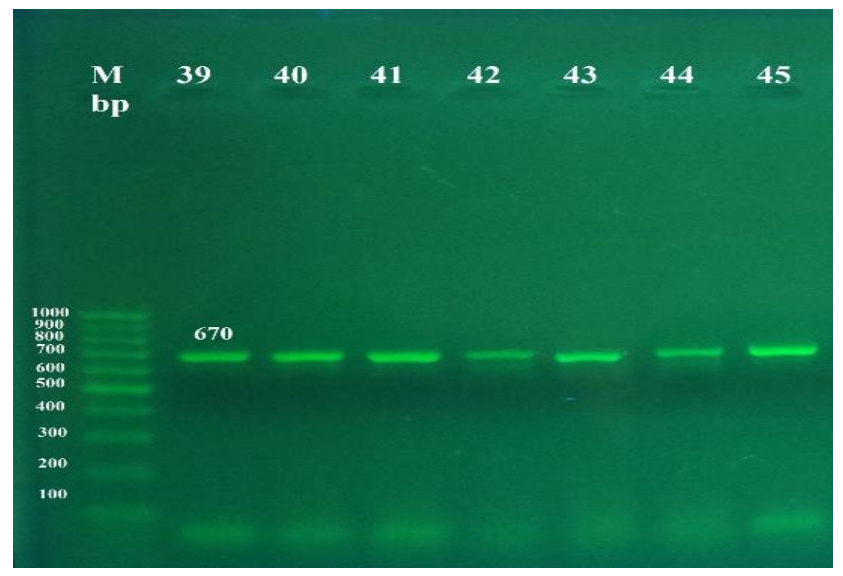


Figure 1: The PCR amplification for species identification of $E$. coli using specific-species uidA primer (670bps) as indicated in lanes 39-45. Amplicons were separated on $1.2 \%$ agarose gel electrophoresis for $1 \mathrm{hr}$. Lane M=DNA marker [100-1000 bps].

Table (5) and Figure (2) show that the rate of infection in females over all ages was higher than that of males with the highest being among the ages $\leq 1-10$ and 11-20 years which was $95.45 \%$. While in males, the highest rate of the infection was reported among the ages $51 \leq$ which was $16.67 \%$. In general, the highest rate of infection with UPEC among both sexes was recorded among the age group $41-50$ years, which is accounted for $46.67 \%$ (21/45). Statistically this rate was significant $(\mathrm{p}<0.013)$ among both sexes and various ages.

Table 5: Distribution of the $E$. coli according to sex and age

\begin{tabular}{lccccccc}
\hline \multirow{2}{*}{$\begin{array}{c}\text { Age groups } \\
\text { (years) }\end{array}$} & $\begin{array}{c}\text { No. of } \\
\text { examined }\end{array}$ & \multicolumn{2}{c}{$\begin{array}{c}\text { Total No. of } \\
\text { infections }\end{array}$} & \multicolumn{4}{c}{ Sex } \\
\cline { 5 - 9 } & samples & No. & \% & No. & \% & No. & \% \\
\hline$\leq 1-10$ & 54 & 22 & 40.74 & 21 & 95.45 & 1 & 4.55 \\
$11-20$ & 73 & 22 & 30.14 & 21 & 95.45 & 1 & 4.55 \\
$21-30$ & 121 & 44 & 36.36 & 40 & 90.91 & 4 & 9.09 \\
$31-40$ & 70 & 20 & 28.57 & 18 & 90.00 & 2 & 10.00 \\
$41-50$ & 45 & 21 & 46.67 & 18 & 85.71 & 3 & 14.29 \\
$51 \leq$ & 37 & 12 & 32.43 & 10 & 83.33 & 2 & 16.67 \\
Total & 400 & 141 & 35.25 & 128 & 32.00 & 13 & 3.25 \\
\hline${ }^{*} \mathrm{P}<0.013$ & & & & & & & \\
\hline
\end{tabular}




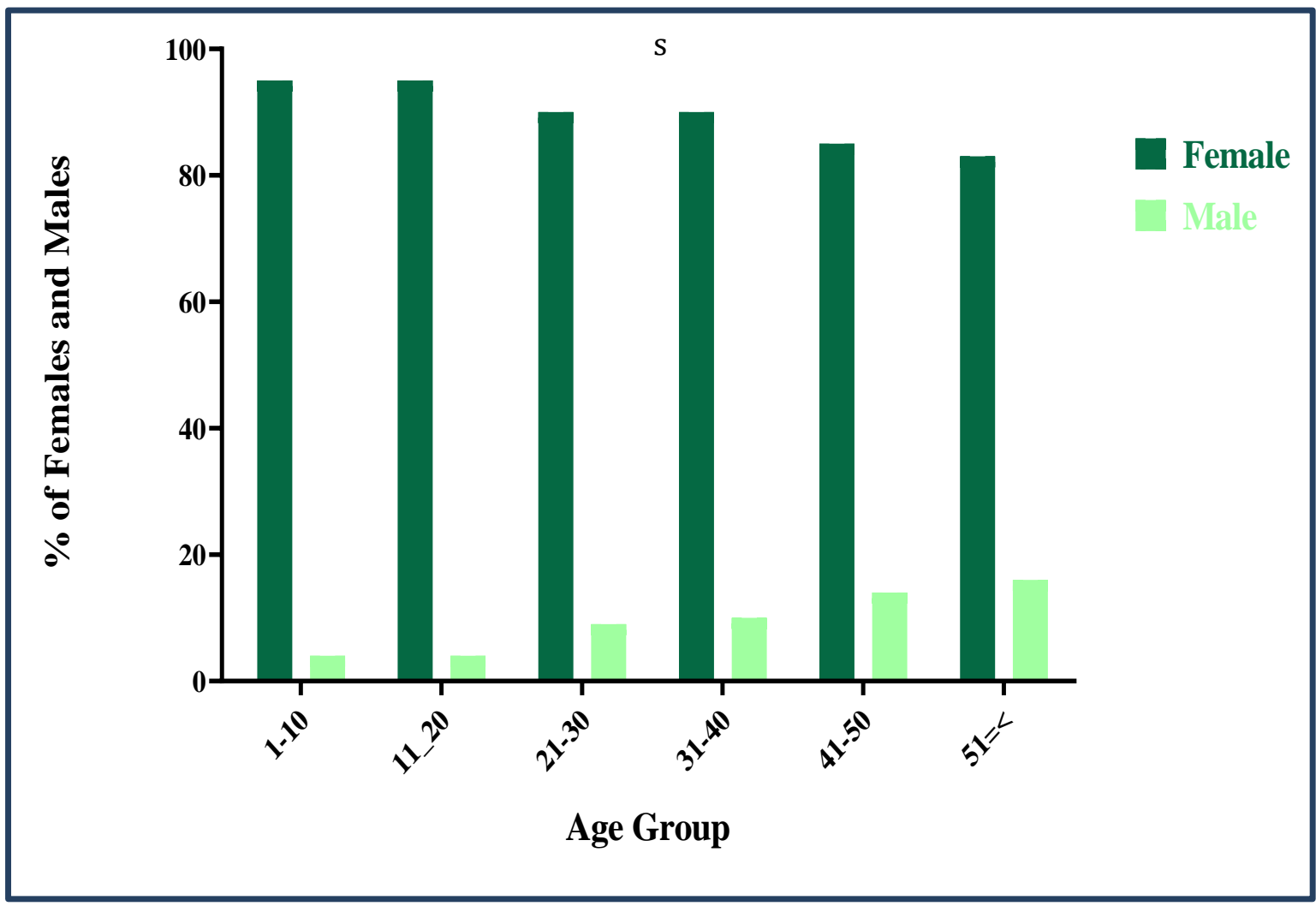

Figure (2): Distribution of $E$. coli according to sex and age

Table (6) refelect the distribution of E. coli according to marital status, among which the highest rate of UPEC cases was recorded which was $38.00 \%(76 / 141)$ as compared to umarried people, but statistically, this difference was non-significant $(\mathrm{P}>0.05)$.

Table 6: Distribution of $E$. coli according to marital status

\begin{tabular}{|c|c|c|c|c|c|c|c|}
\hline \multirow{3}{*}{$\begin{array}{c}\text { Marital } \\
\text { Status }\end{array}$} & \multirow{3}{*}{$\begin{array}{c}\text { No. of } \\
\text { examined } \\
\text { samples }\end{array}$} & \multirow{2}{*}{\multicolumn{2}{|c|}{$\begin{array}{l}\text { Total No. of } \\
\text { Infections }\end{array}$}} & \multicolumn{4}{|c|}{ Sex } \\
\hline & & & & \multicolumn{2}{|c|}{ Females } & \multicolumn{2}{|c|}{ Males } \\
\hline & & No. & $\%$ & No. & $\%$ & No. & $\%$ \\
\hline Married & 200 & 76 & 38.00 & 67 & 88.16 & 9 & 11.84 \\
\hline Single & 200 & 65 & 32.50 & 61 & 93.85 & 4 & 6.15 \\
\hline Total & 400 & 141 & 35.25 & 128 & 32.00 & 13 & 3.25 \\
\hline
\end{tabular}

The occurrence of UPEC among both married and single patients of different ages was higher in females than males, as shown in Figure (3), with the highest rate (31.34\%) being within the ages 21-30 years. On the other hand, the highest rate (33.33\%) of UPEC among single females, was in ages of $\leq 1-10$ years. Regarding males, the highest rate in married males was 
recorded among the ages $41-50$ years which was $33.33 \%$, while in single males, the highest rate of infection was $50 \%$ in ages of 21-30 years.

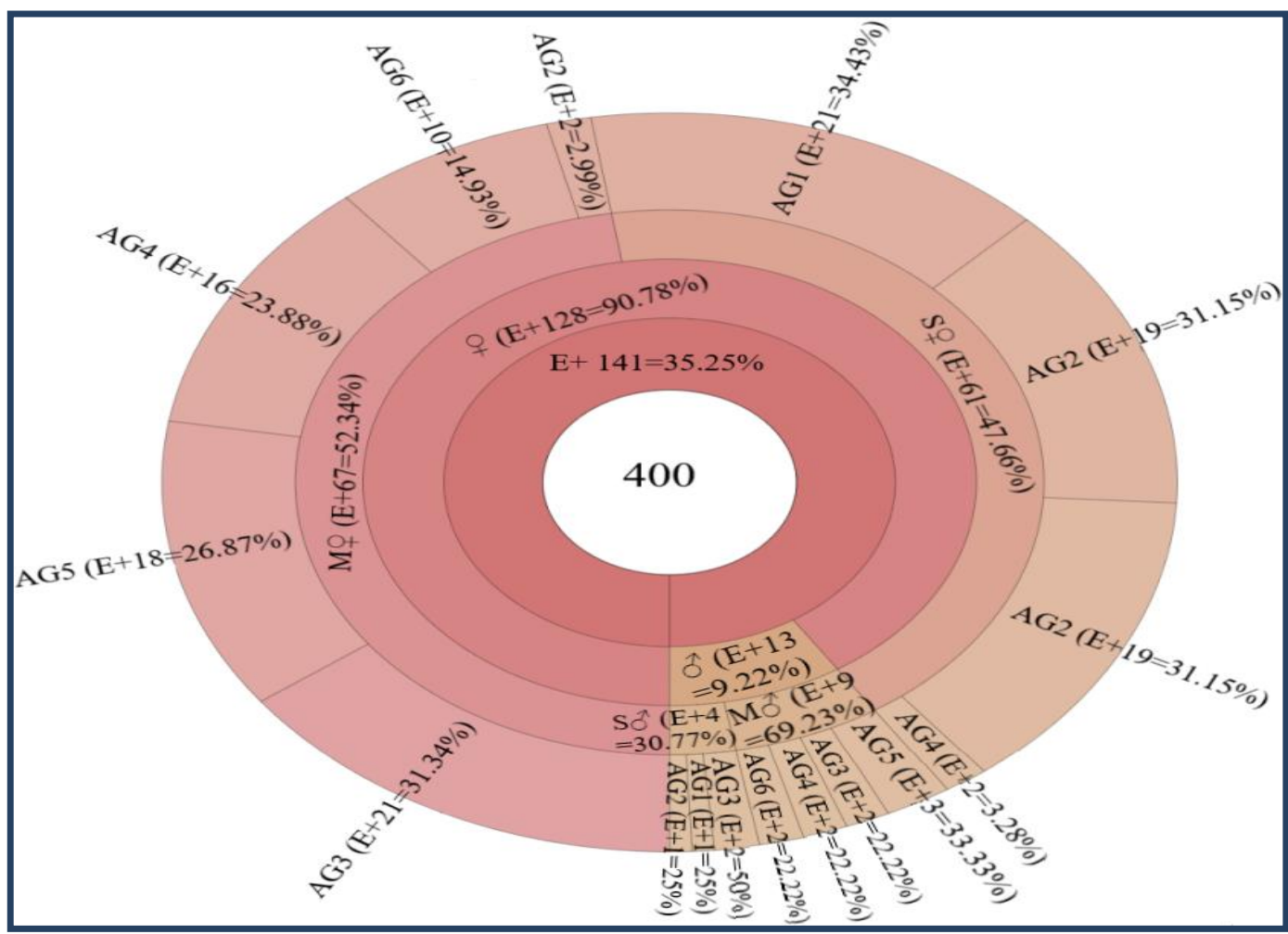

Figure 3: Distribution of $E$. coli according to marital status and age

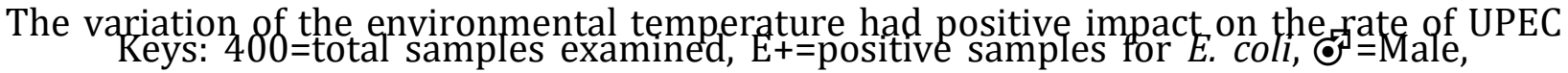
infection as shown in Table (7), which indicate that the number of E. coli at average high $\$=$ Female, $M=$ married, $S=$ single, $A G 1=$ age group $\leq 1-10, A G 2=$ age group 11temprature months $\left(30.7^{\circ} \mathrm{C}\right)$ was higher $(39.57 \%)$ as compared with that of average low 20, AG3=age group 21- 30, AG4=age group 31- 40, AG5=age group 41-50, temperature months $\left(13.3^{\circ} \mathrm{C}\right)$ which was $31.46 \%$.

AG6=51 $\leq$.

Table 7: Incidence of UPEC during high and low temperature months

\begin{tabular}{lccc}
\hline \multirow{2}{*}{$\begin{array}{c}\text { Various temperature }{ }^{\circ} \mathbf{C} \\
\text { and months }\end{array}$} & $\begin{array}{c}\text { No. of examined } \\
\text { samples }\end{array}$ & \multicolumn{2}{c}{$\begin{array}{c}\text { Total no. of } \\
\text { infections }\end{array}$} \\
\cline { 3 - 4 } & 187 & 74 & 39.57 \\
\hline $\begin{array}{l}\text { Jul-Sept (Mean temp. } \\
30.7^{\circ} \mathrm{C} \text { ) }\end{array}$ & 213 & 67 & 31.46 \\
Oct-Jan (Mean temp. 13. $3^{\circ} \mathrm{C}$ ) & 400 & 141 & 35.25 \\
Total & & & \\
\hline
\end{tabular}


With regard to residency, that the highest prevalence of UPEC was among patients living in Zakho city which was $40.56 \%$ as compared to the rate of patients living in villages and camps (Table. 8). Statistically the differences between sex and residency was extremely significant $(\mathrm{P}<0.000001)$.

Table 8: Distribution of UPEC according to residency

\begin{tabular}{lccccccc}
\hline \multirow{2}{*}{ Residence } & $\begin{array}{c}\text { No. of } \\
\text { examined }\end{array}$ & \multicolumn{2}{c}{$\begin{array}{c}\text { Total no. of } \\
\text { infections }\end{array}$} & \multicolumn{2}{c}{ Females } & \multicolumn{2}{c}{ Males } \\
\cline { 3 - 8 } & samples & No. & \% & No. & $\%$ & No. & \% \\
\hline City & 323 & 131 & 40.56 & 120 & 91.60 & 11 & 8.40 \\
Villages & 36 & 5 & 13.89 & 3 & 60.00 & 2 & 40.00 \\
Camps & 41 & 5 & 12.20 & 5 & 100 & 0 & 0 \\
Total & 400 & 141 & 35.25 & 128 & 32.00 & 13 & 3.25 \\
\hline$*$ P<0.000001 & & & & & & & \\
\hline
\end{tabular}

\section{Discussion}

Uropathogenic E. coli is the predominant bacteria that cause UT infections in humans of both sexes and all ages. [25] In the present study, the rate of UPEC among enrolled outpatients was 35.25\%. Higher rates of infection than the present study were recorded in Iraq and other countries such as: In Baghdad and Anbar cities-Iraq, E. coli was reported at a rate of 40.86\%, [18] while in Kerbala city, a higher rate [44.64\%] was reported in 110 examined urine samples. [6]

The gene uidA encodes for E.coli which is the inducible $\beta$-D-glucuronidase enzyme.[30] Thus, almost all studies have used this gene as a molecular marker for E.coli identification. [1] The length of uidA gene reported in this study was 670 bps, Similarly in Duhok-Kurdistan region/Iraq, also the sam length (670 bp) for this gene was reported. [32] While a slightly shorter than that reported in the current study (658 bps) using the same primer sequence was recorded.[1] The variation in the length in both studies might be attributed to the fact that genes usually contain several repeats of the coding microsatellite (1-10 bps) and minisatellite (>10 bps), which are very dynamic components of genomes and are subcategories of tandem repeats (TRs) which makes up the genomic repetitive regions. [21,31] This variation may provide functionally diversion in the cell surface of the antigen that allows the cells for rapid adaptation to the fluctuating environment and/or the evasion of the immune system of the host. [29] 
Similarly a comparable occurrence of UPEC among both sexes have been reported in Duhok city-Iraq, in which females showed a much higher rate than males (81.3\% vs 18.68\%), respectively. [31] Moreover, variable prevalence of UPEC among different ages in this study is somewhat similar to other studies, such as in Duhok city, the highest infection rate [61.96\%] with UPEC was recorded among ages of 31 to 45. [20] While other studies reported different results such as: in India they reported the highest rate(51.15\%) of E. coli infection among females aged 21-40 years, while it was 53.84\% among males aged 40 to 80 years. [16]

Over all ages, the risk of UTI infection in females was higher than that of males. ${ }^{42]}$ This could be attributed to a variety of factors, such as; the anatomical structure of the urinary tract, sexual intercourse, personal hygiene and number of pregnancies. [2] These differences make females more susceptible to pathogens and allow them to access to the bladder. [33] Furthermore, about $40-50 \%$ of females during their lives may have at least one symptomatic UTI [2] and about 20-30\% of adult females approximately can experience recurrence UTI within 6 months after primary infection by UTI, and about 3\% will experience a third infection. [25] This picture is slightly different in elder men, where increasing prostatic hypertrophy may obstruct the urine flow and increase the risk of developing a UTI. Generally, in elder people, UTIs are the most common bacterial infections, which oftenly are asymptomatic. [26] In infants, although breastfeeding reduces the risk of infection with UTI, [42] but several other factors can fascilitate $E$. coli infection such as, weak body structure, incomplete development of the child's immune system, and incorrect methods for cleaning the anal area. [7]

The prevalence of UPEC among both married and single people was higher in females than males, but generally married pepole aged 21 to 50 years showed higher rates, while in single ones the infection was higher at ages between $\leq 1$ to 30 years. The most probabile reason for the higher rate of infection with UPEC among married people at ages of 21-50 years is due to the sexual activities at these ages. [17] While among single people, low rates were recorded among ages of 31-40 years because at this age the females are more mature and can protect themselves from infection. [28]

The variable occurrance of UPEC at different months of the year, with higher rates in warm months is in accordance to the previous study in Zakho city in which the majority of uropathogenic infections occurred at high temperature months than that of low temperature months which were $36.71 \%$ vs $29.69 \%$, respectively. [5] The risk of UTIs increases with the increase of the environmental temperature, this might be due to the increase in the rate of 
deydration at warm temperature that reduce the protection against UTIs, therefore, the incidence of UTIs is increased by $8-20 \%$ during the summer months relative to the winter months. ${ }^{[37]}$ Drinking a high amount of fluid enhances high urine excretion which decreases the incidence or recurrence of UTI while consuming small amounts of water causes a decrease in urine outpouring, which leads to an increased incidence of UTI. [5]

Regarding residency, the rate of UTIs was higher in people living in the city. Similarly in Erbil city/Kurdistan region, the incidence of UTIs among females and males living in urban areas were higher than those living in rural areas, which were $76.1 \%$ and $54.7 \%$, and $45.3 \%$ and 23.9\%, respectively. [19] Furthermore, in Palestine the prevalence of E. coli among patients who live in the city was higher than those living in camps and villages which were $33.3 \%, 20.5 \%$ and 18.8\%, respectively. [36] This may be due to the contribution of other bacteria besides UPEC in these infections. [12] This is not only due to different living style in the urban compared with the rural but also the high population density, however, more studies are required in this direction.

\section{Conclusion}

The UPEC strain is the most common pathogen which causes UTIs in humans of both sexes and at all ages. The uidA primer gave successful identification of uidA gene in the tested E.coli isolates, that confirme final diagnosis of E. coli. Females over all ages showed higher rates than males. It is worthwhile to mention that various risk factors facilitate the spreading of E.coli among the community.

\section{References}

[1] Adamus-bialek, W., Wojtasik, A., Majchrzak, M., Sosnowski, M. and Parniewski, P. 2009. (CGG) 4-Based PCR as a Novel Tool for Discrimination of Uropathogenic Escherichia coli Strains: Comparison with Enterobacterial Repetitive Intergenic Consensus-PCR. J Clin Microbiol, 47(12):3937-3944.

[2] Akhtar, N., Rahman, R., Sultana, S. and Rahman, M.R. 2017. Antimicrobial Sensitivity Pattern of Bacterial Pathogens Associated with Urinary Tract Infection. Delta Med Coll J, 5(2):57-62.

[3] Akinloye, O., Ogbolu, D.O., Akinloye, O.M. and Terry Alli, O.A. 2006. Asymptomatic bacteriuria of pregnancy in Ibadan, Nigeria: A re-assessment. Br J Biomed Sci, 63(3):109112.

[4] Al-barzinji, R., Esmahil, S., Sulaiman, S. and Rageem, S.Gh. 2010. Effect of some antimicrobial 
agents on isolated bacteria from patients with urinary tract infection in Kurdistan Region. Zanco Journal of Medical Sciences, 14(2):61-67.

[5] Al-berfkani, M.I., Allu, M.A. and Mousa, S.A. 2016. The effect of climate temperature and daily water intake on the diversity of uropathogens causing urinary tract infections in adult hospital patients. Diyala J Med,11(1):62-69.

[6] Al-Hasnawi, A.T.N., Zaid, D.A.A. and Al-Hasnawy, H.H. 2019. Immunological and Molecular study of interleukin-17A and Uropathogenic E. coli among Patients in Holy Karbala, Iraq. Journal of Pure and Applied Microbiology, 13(2):967-973.

[7] Al-Taai, H.R.R., Al-Je Ban, Z.A.S., Khalaf, B.H. and Mohammed, Y.Q. 2018. Antibiotic resistance patterns and adhesion ability of uropathogenic Escherichia coli in children. Iraqi Journal of Biotechnology, 17(1):18-26.

[8] Ali, I., Kumar, N., Ahmed, S. and Dasti, J.I. 2014. Antibiotic resistance in uropathogenic E. coli strains isolated from non-hospitalized patients in Pakistan. J Clin Diagnostic Res, 8(9):DC01DC04.

[9] Angshumanjana, Anirbanjana, Dipjitdey, Arijitmajumdar, Jayantabikashdey, and Tudu N. 2016. Selection of Storage Methods for Maintenance of Different Stock Cultures. Int J Curr Microbiol and Appl Sci, 5(10):1097-1104.

[10] Beyene, G. and Tsegaye W. Bacterial uropathogens in urinary tract infection and antibiotic susceptibility pattern in Jimma university specialized hospital, Southwest Ethiopia. Ethiop J Helath Sci, 21(2):141-146.

[11] Croxen, M.A., Law, R.J., Scholz, R., Keeney, K.M., Wlodarska, M. and Finlay B.B. 2013. Recent Advances in Understanding Enteric Pathogenic Escherichia coli. Clin Microbiol Rev, 26(4):822-880.

[12] de Lusignan, S., McGee, C., Webb, R., Joy, M., Byford, R., Yonova, I., Hriskova, M., Matos Ferreira, F., Elliot, A. J., Smith, G. and Rafi, I. 2018. Conurbation, Urban, and Rural Living as Determinants of Allergies and Infectious Diseases: Royal College of General Practitioners Research and Surveillance Centre Annual Report 2016-2017. JMIR Public Heal Surveill, 4(4):e11354.

[13] Engelkirk, P.G. nad Duben-Engelkirk, J. 2008. Laboratory Diagnosis of Infectious Diseases. Wilkins LW and, editor. USA. 303-306 p.

[14] Eto, D.S., Jones, T.A., Sundsbak, J.L. and Mulvey, M.A. 2007. Integrin-mediated host cell invasion by type 1-piliated uropathogenic Escherichia coli. PLoS Pathog, 3(7):0949-0961. 
[15] Forbes, B.A., Sahm, D.F., Weissfeld, A.S. and Bailey, W.R. 2007. Baily and Scott's Diagnostic Microbiology. 12th editi. Wilson L, editor. USA. 842 p .

[16] Goyal, S. and Beniwal, V. 2016. Study of Multidrug Resistance Pattern among Escherichia coli isolated from patients with Urinary tract infection. Asian J Pharm Clin Res, 9(6):157.

[17] Griebling, T.L. 2001. Urinary tract infections in women. Urologic Diseases in America. 589$617 \mathrm{p}$.

[18] Hassan, M.H., Flayih, M.T., Yaseen, N.Y. and Suleiman, A.A. 2015. Detection the Virulence Factor (Cytotoxic necrosis factor1) Produce from Uropathogenic Escherichia coli Isolates. Iraqi J Sci, 56(3A):1920-1924.

[19] Hussein, K.A., Palpitany, S.A. and Ahmad, S.H. 2014. Prevalence of Urinary Tract Infection among Secondary School Students in Urban and Rural in Erbil : Comparative Study. Kufa J Nurs Sci, 4(3):1-6.

[20] Hussein, N.R., Daniel, S., Salim, K. and Assafi, M.S. 2018. Urinary Tract Infections and Antibiotic Sensitivity Patterns Among Women Referred to Azadi Teaching Hospital, Duhok, Iraq. Avicenna J Clin Microbiol Infect, 5(2):27-30.

[21] Ibrahim, M.S., Khalid, H.M. and Mero, W.M.S. 2020. Molecular Characterization of Some Virulence Genes and Antibiotic Susceptibility Pattern among Uropathogenic Escherichia coli Isolated from Patient in Zakho City/Iraq. ZANCO J Pure Appl Sci, 32(2):167-177.

[22] Jameel, A.Y. and Artoshi, D.M.E. 2019. Prevalence of Urinary Tract Infections and Their Antimicrobial Sensitivity Among Diabetic and Non Diabetic Patients in Zakho. Sci J Univ Zakho, 7(4):125-131.

[23] KİreçcI, E., Sleman, D., Ahmed, D., Rahman, D.B. and Yazdee, F.S. 2015. Identification of the bacterial types that cause urinary tract infection and antimicrobial susceptibility in Erbil. Sky Journal of Microbiology Research, 3(1):11-14.

[24] Kucheria, R., Dasgupta, P., Sacks, S., Khan, S. and Sheerin, N. 2005. Urinary tract infections: New insights into a common problem. Postgrad Med J, 81(952):83-86.

[25] Kudinha, T. 2017. The Pathogenesis of Escherichia coli Urinary Tract Infection. In: We Are IntechOpen, the World's Leading Publisher of Open Access Books Built by Scientists, for Scientists, 45-69.

[26] Kumar, P. and Clark, M. 1996. Clinical medicine. In: 3rd Ed. London philadlphia Toronto Sydney Tokyo.

[27] Leboffe, M.J. and Pierce, B.E. 2011. Photographic Atlas for the Microbiology Laboratory. 4th 
editio. USA: Douglas N. Morton.

[28] Lema, V. and Lema, A. 2018. Sexual Activity and the Risk of Acute Uncomplicated Urinary Tract Infection in Premenopausal Women: Implicationsfor Reproductive Health Programming. Obstet Gynecol Int J, 9(1):55-61.

[29] Levdansky, E., Romano, J., Shadkchan, Y., Sharon, H., Verstrepen, K.J., Fink, G. and Osherov, N. 2007. Coding Tandem Repeats Generate Diversity in Aspergillus fumigatus Genes. Eukaryot Cell, 6(8):1380-1391.

[30] Martins, M.T., Rivera, I.G., Clark, D.L., Stewart, M.H., Wolfe, R.L. and Olson, B.H. 1993. Distribution of uidA gene sequences in Escherichia coli isolates in water sources and comparison with the expression of $\beta$-glucuronidase activity in 4- methylumbelliferyl- $\beta$-Dglucuronide media. Appl Environ Microbiol, 59(7):2271-2276.

[31] Merza, N.S. 2013. Clonal Grouping of Uropathogenic Escherichia coli Using Different molecular Typing Methods in Kurdistan Region-Iraq. PhD Dissertation, College of Science, University of Zakho, Iraq.

[32] Merza, N.S., Al Deen, I.H.F., Khalid, H.M., Zaynab, H. and Jubrael, J.M.S. 2016. Molecular Characterization of Extended Spectrum B-lactamase Producing Escherichia coli Isolated from Urine in Kurdistan Region-Iraq. Int J Chem Biomol Sci, 2(2):51-55.

[33] Qadir, H.A.H., Abdulla, A.B.A.S. and Abduljabbar, H.N. 2018. Molecular Study of Some Virulence Factors of Escherichia coli Isolated From Patients with Urinary Tract Infection In Wasit Province. Al- Kut Univ Coll J, 3(2):39-50.

[34] Rivas, L., Glen, E., Mellor, G. K. and Fegan N. 2015. Detection and Typing Strategies for Pathogenic Escherichia coli. Springer B. (Springer. Hartel RW editor, ed.).

[35] Rodríguez, J.M., Murphy, K., Stanton C, Ross, R. P., Kober, O. I., Juge, N., Avershina, E., Rudi, K., Narbad, A., Jenmalm, M. C. Marchesi, J. R. and Collado, M. C. 2015. The composition of the gut microbiota throughout life, with an emphasis on early life. Microb Ecol Heal Dis, 26 (26050):1-17.

[36] Run, I.A. 2008. Community-Acquired Urinary Tract Infection Causing Microorganisms Among Paraplegic Patients in Gaza. Master Thesis in community Mantal Health. Islamic University-Gaza.

[37] Simmering, J.E. 2016. Seasonality, Local Weather and Infectious Disease: Effects of Heat and Humidity on Local Risk for Urinary Tract Infections and Legionella Pneumonia. PhD Dissertation, University of Iowa. 
[38] Tabasi, M., Asadi Karam, M.R., Habibi, M., Yekaninejad, M.S. and Bouzari, S. 2015. Phenotypic Assays to Determine Virulence Factors of Uropathogenic Escherichia coli (UPEC) Isolates and their Correlation with Antibiotic Resistance Pattern. Osong Public Heal Res Perspect, 6(4):261-268.

[39] Tarchouna, M., Ferjani, A., Ben-Selma, W. and Boukadida, J. 2013. Distribution of uropathogenic virulence genes in Escherichia coli isolated from patients with urinary tract infection. Int J Infect Dis, 17(6):e450-e453.

[40] Terlizzi, M.E., Gribaudo, G. and Maffei, M.E. 2017. UroPathogenic Escherichia coli (UPEC) infections: Virulence factors, bladder responses, antibiotic, and non-antibiotic antimicrobial strategies. Front Microbiol, 15(8):1566.

[41] Wagenlehner, F.M.E., Hoyme, U., Kaase, M., Fünfstück, R., Naber, K.G. and Schmiemann, G. 2011. Uncomplicated Urinary Tract Infections. Dtsch Arztebl Int, 108(24):415-423.

[42] Zahera, M., Rastogi, C., Singh, P., Iram, S., Khalid, S. and Kushwaha, A. 2011. Isolation, Identification and Characterization of Escherichia coli from Urine Samples and their Antibiotic Sensitivity Pattern. Eur J Exp Biol, 1(2):118-124. 